\title{
POTENSI PEMANFAATAN KITOSAN TERMODIFIKASI ASAP CAIR SEBAGAI BAHAN EDIBLE COATING ANTI MIKROBA UNTUK PENGAWETAN DAGING
}

\author{
POTENTIAL UTILIZATION OF LIQUID SMOKE MODIFIED CHITOSAN AS \\ AN ANTIMICROBIAL EDIBLE COATING FOR MEAT PRESERVATION
}

\author{
M. Hanafiah, M. Faisal, Izarul Machdar \\ Program Studi Magister, Jurusan Teknik Kimia, Fakultas Teknik, Universitas Syiah Kuala, Jl. Syech A Rauf \\ no. 7 Darussalam, Banda Aceh, Aceh 23111, Indonesia \\ Email:mfaisal@unsyiah.ac.id
}

\begin{abstract}
Abstrak
Penelitian ini merupakan kajian awal pemanfaatan kitosan yang dimodifikasi dengan asap cair untuk menghasilkan bahan edible coating yang dapat digunakan sebagai pengawet daging sapi. Senyawa kitosan diperoleh dari limbah kulit udang, sedangkan asap cair dihasilkan dari pirolisis cangkang kelapa sawit pada suhu $340^{\circ} \mathrm{C}$. Larutan edible coating dengan berbagai konsentrasi dibuat dengan cara melarutkan kitosan (1-1,5\%) kedalam asap cair 3\%, yang selanjutnya diaplikasikan sebagai pengawet daging. Sampel daging yang sudah dicelupkan edible coating selama 15 menit, kemudian disimpan didalam lemari pendingin dan diamati penurunan daya tahannya setiap 24 jam selama 8 hari. Hasil pengujian asap cair menggunakan Gas Chromatography-Mass Spectrometry $(G C-M S)$ menunjukkan bahwa asap cair mengandung senyawa fenol dan asam asetat yang memiliki sifat antimokrobial. Uji ketahanan daging dilakukan dengan menganalisa aroma, tekstur dan warna daging. Hasil penelitian menunjukkan bahwa daging sapi yang telah dilapisi larutan kitosan-asap cair dapat bertahan hingga 7 hari. Konsentrasi kitosan mempengaruhi daya tahan daging, semakin besar konsentrasi kitosan maka daya tahan daging semakin baik. Konsentrasi optimum diperoleh pada $1 \%$ kitosan, padakondsi tersebut daging masih memiliki aroma, tekstur dan warna yang dapat diterima hingga waktu 6 hari. Hal ini menunjukkan bahwa asap cair-kitosan dapat digunakan sebagai bahan edible coating.
\end{abstract}

Kata kunci: asap cair, kitosan, edible coating, pengawet daging

\begin{abstract}
This research is a preliminary study of the utilization of chitosan modified with liquid smoke to produce edible coating material that can be used as a preservative of beef. Chitosan compounds obtained from shrimp shell waste, while liquid smoke produced from pyrolysis of palm shells at a temperature of $340^{\circ} \mathrm{C}$. Edible coating solution with various concentrations was made by dissolving chitosan (1-1.5\%) into 3\% liquid smoke, which was then applied as a meat preservative. Meat samples that have been dipped edible coating for 15 minutes, then stored in the refrigerator and observed decreased endurance every 24 hours for 8 days. Analysis results of Gas ChromatographyMass Spectrometry (GC-MS) showed that liquid smoke contains phenol and acetic acid compounds that have antimocrobial properties. Meat endurance test was done by analyzing the aroma, texture and color of meat. The results showed that the beef that has been coated liquid chitosan solution can last up to 7 days. Chitosan concentration affects the endurance of meat, the greater the chitosan concentration, the better the meat endurance. The optimum concentration was obtained at $1 \%$ of chitosan, the meat still has an acceptable aroma, texture and color for up to 6 days. This suggests that chitosan-liquid smoke can be used as an edible coating material.
\end{abstract}

Keywords: liquid smoke, chitosan, edible coating, meat preservative

\section{Pendahuluan}

Indonesia merupakan merupakan salah satu negara agragris yang memiliki kekayaan dari sumber daya alam yang cukup melimpah. Dengan luas lahan yang besar, sektor pertanian dapat dikembangkan untuk mensejahterakan kehidupan masyarakat. Pembangunan disektor pertanian, selain membawa dampak yang sangat positif bagi kesejahteraan masyarakat Indonesia, juga mempengaruhi jumlah limbah biomassa dari hasilhasil pertanian dan perkebunan. Peningkatan produksi pertanian akan sebanding dengan limbah 
hasil pertanian yang dihasilkan. Hingga saat ini potensi berbagai limbah biomassa pertanian belum dimanfaatkan dengan baik, padahal Indonesia adalah negara agraris yang memiliki banyak biomassa pertanian. Salah satu industri terbesar di Indonesia adalah kelapa sawit yang menghasilkan banyak limbah biomassa seperti cangkang sawit, pelepah dan tandan kosong yang belum termanfaatkan dengan baik. Baru sekitar $40 \%$ dari cangkang sawit digunakan untuk energi, sedangkan pelepah dan tanda kosong biasanya disebarkan di kebun sawit, sehingga dapat melepaskan emisi gas rumah kaca. Salah satu metode untuk memanfaatkan potensi limbah biomassa kelapa sawit di Indonesia adalah dengan cara mempirolisis limbah tersebut sehingga menghasilkan produk asap cair yang dapat digunakan sebagai pengawet nabati. Beberapa penelitian menunjukkan bahwa senyawa asap cair mengandung senyawa yang bersifat antibakteri dan antioksidan $[7,11,12]$.

Bahan nabati lain yang dapat dimanfaatkan sebagai pengawet adalah kitosan, yang merupakan kopolimer D-glucosamine dan N-acetyl-Dglucosamine, yang diperoleh dari proses alkali atau deasetilasi dari kitin. Gugus asetil mempengaruhi interaksi ion dalam kitosan. Semakin banyak gugus asetil yang hilang dari kitosan, maka interaksi antar ion dan ikatan hidrogen dari kitosan akan semakin kuat [23]. Dalam perkembangannya, kitosan biasanya dicampurkan dengan asam asetat sebagai pelarut untuk menghasilkan edible coating. Disisi lain, asap cair yang mengandung senyawa asam juga berpotensi menggantikan asam asetat yang selama ini digunakan.

Namun demikian hingga saat ini penelitian yang mendalam tentang uji efektifitas asap cair kitosan sebagai bahan pengawet alami belum dilakukan. Sehingga diperlukan inovasi baru untuk menghasilkan asap cair-kitosan yang sesuai digunakan sebagai bahan pengawet daging. Pemanfaatkan limbah dan bahan organik produk samping sebagai pengawet alami akan menghasilkan nilai tambah ekonomis dan peningkatan nilai sosial budaya. Pengendalian umur simpan produk dengan metode ini juga dapat menjaga keseimbangan ekosistem dan berdampak pada faktor kesehatan dan kualitas produk pangan. Penelitian ini bertujuan untuk mengkaji pemanfaatan asap cair yang dikombinasikan dengan kitosan sebagai pengawet alami daging sapi pada penyimpanan suhu dingin.

\section{Teori}

Asap cair merupakan cairan kondensat uap asap hasil pirolisis bahan kayu yang mengandung senyawa penyusun utama seperti asam, fenol dan karbonil [5]. Senyawa asap cair ini mengandung senyawa-senyawa yang berfungsi sebagai antibakteri, anti jamur dan senyawa antioksidan $[1,2,4,20,21]$, sehingga dapat menjadi bahan alami dalam pengawetan makanan. Beberapa penelitian sebelumnya menunjukkan bahwa asap cair dapat digunakan untuk mengawetkan tahu [10], bakso dan ikan [7,13].

Disisi lain, kitosan juga merupakan bahan pengawet alami yang saat ini sedang dikembangkan. Kitosan dari kulit udang dapat digunakan untuk mengawetkan beberapa bahan makanan seperti daging sapi dan ayam [6,22]. Kitosan merupakan turunan yang paling sederhana dari senyawa kitin. Kitosan sudah banyak diaplikasikan oleh industri dalam berbagai bidang. Hal ini dikarenakan adanya gugus amino pada posisi $\mathrm{C}_{2}$ dan gugus hidroksil primer dan sekunder pada posisi $\mathrm{C}_{3}$ dan $\mathrm{C}_{6}$. Kitosan memiliki sifat kimia linier polyamine (poly D-glucosamine), gugus amino yang reaktif dan gugus hidroksi yang reaktif [23]. Senyawa kitosan tidak beracun dan merupakan poli, biopolimer kationik yang dapat dan mudah didegradasi secara alami [9]. Kitosan dapat diperoleh dari limbah perikanan seperti dari kulit udang dan kepiting. Kombinasi asap cair dan kitosan diharapkan dapat memberikan pengaruh yang lebih baik terhadap daya tahan pangan.

\section{Metodologi Penelitian}

Reaktor pirolisis dengan kapasitas $5 \mathrm{~kg} / \mathrm{hari}$ didesain dengan menggunakan bahan stainles steel sehingga produk asap cair yang dihasilkan bebas dari kandungan logam lain. Reaktor dilengkapi dengan alat pengontrol temperatur yang dapat beroperasi hingga suhu $500^{\circ} \mathrm{C}$. Sampel yang berupa limbah cangkang dimasukkan kedalam reaktor selama 5-8 jam dan dipirolisis pada temperatur $340^{\circ} \mathrm{C}$. Asap yang keluar dikondensasikan supaya menjadi asap cair dengan menggunakan distilasi yang terbuat dari bahan stainles steel. Asap cair yang didapatkan merupakan grade 3. Selanjutnya asap cair dimurnikan dengan cara destilasi pada temperatur $190^{\circ} \mathrm{C}$. Proses pembuatan asap cair yang lebih detail dapat dilihat pada penelitian sebelumnya $[11,14]$. Senyawa atau Komponen kimia yang terdapat dalam asap cair akan diidentifikasi dengan menggunakan GC-MS berdasarkan metode yang dikembangkan oleh modifikasi Guillen and Ibargoitia [15,16]. 
Kitosan yang digunakan adalah kitosan komersial yang berasal dari dari kulit udang (Kitosan Pharmaceutial Medical Grade, CV. ChiMultiguna). Kemampuan asap cair-kitosan sebagai pengawet alami diuji pada daging sapi. Larutan asap cair 3\% ditambahkan kitosan sebanyak 0,5;1 dan 1,5 gram kitosan, kemudian dilarutkan dalam $100 \mathrm{ml}$ aquadest. Daging sapi kemudian dicelupkan kedalam masing masing konsentrasi asap cair-kitosan selama 15 menit, lalu disimpan di lemari pendingin. Pengamatan dilakukan setiap 24 jam selama 8 hari. Parameter yang diamati untuk melihat ketahanan daging adalah aroma, tekstur dan warna daging.

\section{Hasil dan Pembahasan}

\section{Pengujian komposisi asap cair dengan GC-MS}

Asap cair adalah suatu larutan yang berisi senyawa-senyawa organik teroksidasi, seperti kelompok keton, aldehida, phenol, and asam-asam karboksilat yang diperoleh dari proses kondensasi uap hasil proses pirolisis (pembakaran tanpa oksigen) tanaman atau kayu pada suhu sekitar $400^{\circ} \mathrm{C}$ (Soldera 2008). Menurut Prananta (2009), cangkang kelapa sawit mengandung lignin $(29,4 \%)$, hemiselulosa $(27,7 \%)$, selulosa $(26,6 \%)$, air $(8,0 \%)$, komponen ekstraktif $(4,2 \%)$, abu $(0,6 \%)$. Faisal dkk. [11] mengatakan proses pirolisis selulosa menghasilkan senyawa asam asetat dan senyawa karbonil seperti asetaldehid, glikosal dan akreolin. Sedangkan proses pirolisis lignin akan menghasilkan senyawa fenol, guaiakol, siringol bersama dengan homolog dan derivatnya. Jumlah dan macam senyawa yang terkandung didalam asap cair sangat tergantung pada suhu pirolisis dan bahan baku [14]). Data analisa komposisi asap cair pada temperatur $340^{\circ} \mathrm{C}$ setelah proses distilasi ditunjukkan pada Tabel 1 . Awhu dkk. [2] juga mengatakan kandungan senyawa fenol dapat membunuh bakteri pembusuk yang mendegradasi protein menjadi asam-asam amino, sehingga tidak menimbulkan bau busuk. Asap cair juga memiliki sifat bakteristatis yang tinggi sehingga menyebabkan bakteri tidak berkembang biak, dan bersifat fungisidal sehingga jamur tidak dapat tumbuh.
Tabel 1. Kandungan kimia asap cair hasil pirolisis cangkang kelapa sawit pada suhu $340^{\circ}$

\begin{tabular}{|c|c|c|}
\hline $\begin{array}{l}\text { R.Time } \\
\text { (min) }\end{array}$ & $\begin{array}{c}\text { Kons. } \\
(\%)\end{array}$ & Nama \\
\hline 2,885 & 0,25 & $\begin{array}{ll}\text { Cyclopropane, } & \text { 1,1-dibromo-2- } \\
\text { chloro-2-fluoro- } & \text { (CAS) } \\
\text { Dibromo-2-Chloro } & \end{array}$ \\
\hline 5,417 & 10,89 & Acetic acid (CAS) Ethylic acid \\
\hline 5,638 & 5,57 & Acetic acid (CAS) Ethylic acid \\
\hline 5,800 & 0,23 & $\begin{array}{l}\text { Acetic acid, Anhydride with Formic } \\
\text { acid }\end{array}$ \\
\hline 5,878 & 2,21 & $\begin{array}{l}\text { 2-Propanone, 1-hydroxy- (CAS) } \\
\text { Acetol }\end{array}$ \\
\hline 6,335 & 1,19 & Acetic acid (CAS) Ethylic acid \\
\hline 6,417 & 1,15 & Acetic acid (CAS) Ethylic acid \\
\hline 7,715 & 3,47 & Acetic acid (CAS) Ethylic acid \\
\hline 8,603 & 6,26 & Acetic acid (CAS) Ethylic acid \\
\hline 9,046 & 3,12 & Acetic acid (CAS) Ethylic acid \\
\hline 9,421 & 3,01 & Acetic acid (CAS) Ethylic acid \\
\hline 9.866 & 4.40 & Acetic acid (CAS) Ethylic acid \\
\hline 11,092 & 0,59 & 2-Acetyl Furan \\
\hline 11,375 & 0,36 & $\begin{array}{l}\text { 2(3H)-Furanone, dihydro- (CAS) } \\
\text { Butyrolactone }\end{array}$ \\
\hline 11,993 & 0,43 & 2,3-Dimethylcyclohexanol \\
\hline 12,307 & 14,91 & $\begin{array}{l}\text { Carbamic acid, phenyl ester (CAS) } \\
\text { Phenyl carbamate }\end{array}$ \\
\hline 12,678 & 17,77 & $\begin{array}{l}\text { Carbamic acid, phenyl ester (CAS) } \\
\text { Phenyl carbamate }\end{array}$ \\
\hline 13,561 & 6,37 & $\begin{array}{l}\text { Phenol, } \\
\text { Guaiacol }\end{array}$ \\
\hline 14,422 & 1,22 & $\begin{array}{l}\text { Phenol, 2,4-dimethyl- (CAS) 2,4- } \\
\text { Xylenol }\end{array}$ \\
\hline 14,779 & 1,86 & 2-Methoxy-4-methylphenol \\
\hline 15,681 & 0,35 & $\begin{array}{l}\text { Phenol, 4-ethyl-2-methoxy- (CAS) } \\
\text { p-Ethylguaiacol }\end{array}$ \\
\hline 16,851 & 0,36 & $\begin{array}{l}\text { Phenol, 2,6-dimethoxy- (CAS) 2,6- } \\
\text { Dimethoxyphenol }\end{array}$ \\
\hline
\end{tabular}

Hasil Analisis Aroma, Tekstur, dan Warna daging

Aroma

Penggunaan kitosan dengan konsentrasi 0,5-1,5\% digunakan untuk merendam daging sapi selama 15 menit dan disimpan pada refrigerator $4-7^{\circ} \mathrm{C}$. Hasil pengamatan aroma ditunjukkan pada Tabel 2, dapat dilihat bahwa daging sapi yang direndam 
dengan berbagai konsentrasi kitosan memberikan efek perubahan aroma yang berbeda terhadap waktu penyimpanannya. Penambahan kitosan dengan konsentrasi yang tinggi dalam perendaman dapat memperlambat aroma bau pada daging. Daging yang direndam dengan kitosan 1,5\% dan $1 \%$ memiliki aroma yang masih enak selama waktu penyimpanan 7 hari. Sedangkan daging yang direndam dengan kitosan $0,5 \%$ memiliki aroma yang masih enak selama waktu penyimpanan 6 hari. Setelah penyimpanan lebih dari 7 hari, daging sudah mulai mengeluarkan aroma yang kurang sedap.

Tabel 2. Pengamatan aroma daging sapi dengan berbagai konsentrasi kitosan

\begin{tabular}{|c|c|c|c|c|c|c|c|c|c|}
\hline \multirow{3}{*}{$\begin{array}{c}\text { Konsentrasi } \\
\text { Kitosan }\end{array}$} & \multicolumn{8}{|c|}{ Aroma Daging Sapi } \\
\cline { 2 - 9 } & $\mathbf{0}$ & $\mathbf{1}$ & $\mathbf{2}$ & $\mathbf{3}$ & $\mathbf{4}$ & $\mathbf{5}$ & $\mathbf{6}$ & $\mathbf{7}$ & $\mathbf{8}$ \\
\hline $0 \%$ & 5 & 5 & 5 & 5 & 5 & 5 & 5 & 4 & 3 \\
\hline $0,5 \%$ & 5 & 5 & 5 & 5 & 5 & 5 & 5 & 4 & 4 \\
\hline $1 \%$ & 5 & 5 & 5 & 5 & 5 & 5 & 5 & 5 & 4 \\
\hline $1,5 \%$ & 5 & 5 & 5 & 5 & 5 & 5 & 5 & 5 & 4 \\
\hline
\end{tabular}

Keterangan: 1=Sangat bau, 2=Bau, 3=Sedang, $4=$ Sedikit bau, dan $5=$ Tidak bau

\section{Tekstur}

Pengujian tekstur dilakukan dengan menggunakan tangan. Uji ini bertujuan untuk merasakan tekstur suatu produk makanan. Tabel 3 menunjukkan bahwa tekstur daging sapi yang paling baik yaitu pada daging dengan perendaman kitosan dengan konsentrasi 1,5\%, tekstur daging masih keras selama penyimpanan 6 hari. Hasil pengamatan menunjukkan bahwa pada waktu penyimpanan 8 hari sudah mulai sedikit keras menuju lembek. Sedangkan konsentrasi perendaman 0,5 dan 1\% menggunakan kitosan, tekstur daging sapi mulai berubah pada waktu penyimpanan selama 5 hari. Menurunnya nilai tekstur daging sapi disebabkan oleh pertumbuhan mikroorganisme yang terdapat dalam daging sapi selama penyimpanan [18]. Pembusukan pada daging ditandai dengan semakin kecilnya angka nilai pengamatan uji tekstur. Pembusukan dan kerusakan daging terjadi akibat mikroorganisme yang merusak struktur daging sehingga menjadi lunak dan berair [17].
Tabel 3. Pengamatan tekstur daging sapi dengan berbagai konsentrasi kitosan

\begin{tabular}{|c|c|c|c|c|c|c|c|c|c|}
\hline \multirow{2}{*}{$\begin{array}{c}\text { Konsentrasi } \\
\text { Kitosan }\end{array}$} & \multicolumn{7}{|c|}{ Tekstur Daging Sapi } \\
\cline { 2 - 10 } & $\mathbf{0}$ & $\mathbf{1}$ & $\mathbf{2}$ & $\mathbf{3}$ & $\mathbf{4}$ & $\mathbf{5}$ & $\mathbf{6}$ & $\mathbf{7}$ & $\mathbf{8}$ \\
\hline $0 \%$ & 5 & 5 & 5 & 5 & 5 & 4 & 4 & 3 & 2 \\
\hline $0,5 \%$ & 5 & 5 & 5 & 5 & 5 & 5 & 4 & 3 & 3 \\
\hline $1 \%$ & 5 & 5 & 5 & 5 & 5 & 5 & 4 & 3 & 3 \\
\hline $1,5 \%$ & 5 & 5 & 5 & 5 & 5 & 5 & 5 & 4 & 3 \\
\hline
\end{tabular}

Keterangan: 1=Sangat lembek, 2=Lembek, $3=$ Sedikit keras, 4=Agak keras, dan 5= Keras

Warna

Hasil pengamatan warna pada Tabel 1.3 menunjukkan bahwa daging sapi yang direndam dengan berbagai konsentrasi kitosan memberikan efek perubahan warna yang berbeda setiap waktu penyimpanannya. Hasil pengamatan warna pada berbagai konsentrasi menunjukkan warna yang sama pada penyimpanan 0 hingga 3 hari, yaitu masih berwarna merah darah. Hal ini sesuai dengan penelitian Jo dkk.[3] yang menyatakan bahwa dengan penambahan kitosan, panel sensori tidak mendeteksi adanya perbedaan warna yang ditimbulkan. Penelitian Bostan dan Mahan [8] juga menyatakan bahwa pemberian kitosan $(0,25 \%$; $0,5 \%$; dan $1 \%)$ tidak menimbulkan perubahan sensori yang tidak diinginkan, bahkan sampel dengan perlakuan memiliki warna yang lebih cerah daripada kontrol.

Dari tabel 4 dapat dilihat kondisi warna terbaik yaitu daging sapi dengan perendaman kitosan $1,5 \%$, yaitu warna merah darah dapat bertahan selama 7 hari penyimpanan. Pada hari ke-8 daging sapi sudah berubah menjadi warna merah pucat. Sedangkan daging sapi dengan perendaman kitosan 0,5 dan 1\% kitosan daging sapi mengalami perubahan pada hari ke-6 dan ke7 dari merah darah menjadi merah pucat. Daging sapi tanpa kitosan (0\%) sudah mengalami perubahan warna pada hari ke-4 menjadi warna merah pucat. Warna daging merah cerah akan berubah menjadi hijau, coklat atau keabuan akibat senyawa oksidasi (seperti peroksida) atau adanya $\mathrm{H}_{2} \mathrm{~S}$ yang dihasilkan bakteri. Hasil yang diperoleh dari penelitian ini lebih baik dari penelitian sebelumnya [19] dimana daging bertahan dalam 4 hari masa penyimpanan pada konsentrasi kitosan $3 \%$ (menggunakan pelarut asam asetat). 
Tabel 4. Pengamatan warna daging sapi dengan berbagai konsentrasi kitosan

\begin{tabular}{|c|c|c|c|c|c|c|c|c|c|}
\hline \multirow{2}{*}{$\begin{array}{c}\text { Konsentrasi } \\
\text { Kitosan }\end{array}$} & \multicolumn{7}{|c|}{ Warna Daging Sapi } \\
\cline { 2 - 10 } & $\mathbf{0}$ & $\mathbf{1}$ & $\mathbf{2}$ & $\mathbf{3}$ & $\mathbf{4}$ & $\mathbf{5}$ & $\mathbf{6}$ & $\mathbf{7}$ & $\mathbf{8}$ \\
\hline $0 \%$ & 5 & 5 & 5 & 5 & 4 & 4 & 3 & 2 & 2 \\
\hline $0,5 \%$ & 5 & 5 & 5 & 5 & 5 & 5 & 4 & 4 & 3 \\
\hline $1 \%$ & 5 & 5 & 5 & 5 & 5 & 5 & 5 & 4 & 4 \\
\hline $1,5 \%$ & 5 & 5 & 5 & 5 & 5 & 5 & 5 & 5 & 4 \\
\hline
\end{tabular}

\section{Kesimpulan}

Hasil penelitian menunjukkankan edible coating asap cair dari cangkang kelapa sawit yang dimodifikasi kitotan mampu menjadi alternatif pengawet daging sapi. Semakin tinggi konsentrasi kitosan dalam asap cair maka daya tahan daging akan semakin lama. Daging sapi yang diawetkan dengan edible coating dengan konsentrasi kitosan 1\% dapat bertahan hingga 6 hari. Pada kondisi ini, daging masih layak dikonsumsi karena aroma, rasa dan teksturnya masih baik. Sedangkan pada hari ke 8 kondisi daging sudah mulai tidak baik untuk konsumsi.

\section{Ucapan Terima Kasih}

Penulis mengucapkan terimakasih kepada Direktorat Riset dan Pengabdian Masyarakat, Direktorat Jenderal Penguatan Riset dan Pengembangan, Kementrian Riset, Teknologi, dan pendidikan Tinggi atas hibah dan bantuan dana yang diberikan.

\section{Daftar Pustaka}

[1] A. Gani, H. Husni, A. Baihaqi and M. Faisal, Potential development of liquid smoke from oil palm solid waste as biofungicides, International Journal of Science and Engineering, 7, (2014) 65-69.

[2] A. Awhu, R. Paindoman, dan P. Coniwati, Pengaruh variable waktu dan temperatur terhadap pembuatan asap cair dari limbah kayu pelawan (Cynometra Cauliflora), Jurnal Teknik Kimia , 19, (2013)1-8.

[3] C. Jo, J.W. Lee, K.H. Lee, M.W. Byun, Quality properties of pork sausage prepared with water-soluble chitosan oligomer, Meat Science 59, (2001) 369-375.

[4] D.I. Ariestya, F. Swastawati, and E. Susanto, Antimicrobial activity of microencapsulation liquid smoke on tilapia [Oreochromis Niloticus (Linnaeus, 1758)] meat for preservatives in cold storage $\left( \pm 5 \mathrm{C}^{\circ}\right)$, Aquatic Procedia, 7, (2016) 19-27.

[5] I. Zuraida and S. Budijanto, Antibacterial activity of coconut shell liquid smoke (CSLS) and its application on fish ball preservation. International Food Research Journal, 18, (2011) 405-410.

[6] F. Shahidi, J.K.,V Arachchi, and Y.J. Jeon, Food aplication of chitin and chitosan, Trends in Food Science and Technology, 10 (1999) 37-51.

[7] J. Prananta, Pemanfaatan sabut dan tempurung kelapa Sawit untuk pembuatan asap cair sebagai pengawet makanan alami, http://www.scribd.com/doc/4142857

[8] K. Bostan, and F.I. Mahan, Microbiological quality and shelf-life of sausage treated with chitosan, Journal of Faculty Veterinary Medicine, İstanbul Üniversity, 37 (2011) 117126.

[9] K. Kofuji, C.J. Qian, Y. Murata and S. Kawashima, Preparation of chitosan microparticles by water-in-vegetable oil emulsion coalescence technique, Journal of Reactive and Functional Polymers, 65, (2005) 77-83.

[10]L. Ginayati, M. Faisal, dan Suhendrayatna, Pemanfaatan asap cair dari pirolisis cangkang kelapa sawit sebagai pengawet alami tahu, Jurnal Teknik Kimia USU, 4, (2015) 7-11.

[11] M. Faisal, T. Chamzurni, and H. Daimon, A study on the effectiveness of liquid smoke produced from palm kernel shells in inhibiting black pod disease in cacao fruit in vitro, International Journal of GEOMATE, 14, (2018) 36-41.

[12] M. Faisal, A. Gani, Husni, A. Baihaqi, and H. Daimon, Pyrolysis of oil palm kernel shell into liquid smoke and its application to control anthracnose disease on chili (Capsicum annum L.). Journal of Engineering and Applied Sciences, 11, (2016) 25832587.

[13] M. Faisal, and A. Gani, The effectiveness of liquid smoke produced from palm kernel shells pyrolysis as a natural preservative in fish ball. International Journal of GEOMATE, 15(47), (2018) 145-150.

[14] M. Faisal, A. Gani, Husni, and H. Daimon, A Preliminary study of the itilization of liquid smoke from palm kernel shells for organic mouthwash. International Journal of GEOMATE, 13, (2017) 116-120. 
[15] M.D. Guillen and M.L. Ibargoitia, Influence of the moisture content on the composition of the liquid smoke produced in the pyrolysis process of fagus sylvatica L. wood, Journal of Agricultural, and Food Chemistry, 47, (1999) 4126-4136.

[16] M.D. Guillen and M.L. Ibargoitia, New components with potential antioxidant and organoleptic properties, detected for the first time in liquid smoke flavoring preparations, Journal of Agricultural and Food Chemistry, 46, (1998) 1276-1285.

[17] R.S. Harjanti, Kitosan dari limbah udang sebagai bahan pengawet ayam goreng, Jurnal Rekayasa Proses, 8, (2014) 12-18.

[18]R.A. Soegiarto, Doctoral Thesis, Universitas Atma Jaya, Yogyakarta, 2013.

[19]R. Rahardyani, Skripsi, Departemen Teknologi Hasil Perairan, Institut Pertanian Bogor, 2011.

[20] S. Saloko, P. Darmadji, B. Setiaji, and Y. Pranoto, Antioxidative and antimicrobial activities of liquid smoke nanocapsules using chitosan and maltodextrin and its application on tuna fish preservation, Food Bioscience, 7 , (2014) $71-79$

[21] Widawati, Lina, and B. Budiyanto, Pembuatan asap cair tandan kosong kelapa sawit untuk pengawet dan flavouring ikan pindang kembung (Rastrelliger Sp.), Jurnal Agroteknologi, 8(1), (2014) 15-28.

[22]W. Zahiruddin., A.C. Erungan dan I. Wiraswanti, Pemanfaatan karagenan dan kitosan dalam pembuatan bakso ikan kurisi (Nemipterus nematophorus) pada penyimpanan suhu dingin dan beku, Bulletin Teknologi Hasil Perikanan, XI(1), (2008) 4052.

[23]Z.X. Tang, L. Shi, J.Qian, Neutral lipase from aqueous solutions on chitosan nano particles. Journal Biochemical Engineering, 34 (2007) 217-223. 